\title{
An Examination of the Factor Structure of Union Commitment in New Zealand
}

\author{
Roderick D. Iverson and Matt Ballard*
}

This paper examines the stability of the dimensionality of union commitment as proposed by Gordon, Philpot, Burt, Thompson, and Spillers (1980) in the cultural context of New Zealand. The results based on a sample of 489 academic and ancillary (i.e. technical, library, general, and services) staff using the sophisticated technique of confirmatory factor analysis (LISREL VIII) (Jöreskog and Sörbom, 1993) indicate that union commitment is best represented by the four factors of union loyalty, responsibility to the union, willingness to work for the union, and belief in unionism. These factors displayed discriminant validity as evidenced by the differential relationships and explained variances with a common set of explanatory variables. For example, older members were found to be associated with a willingness to fulfil the day to day obligations of the union (i.e. responsibility). No support was found for any effect of gender, kinship responsibility, membership tenure or rank on union commitment. As expected, having represented or previously held a union position significantly influences staff's responsibility and willingness to work for the union. Surprisingly, academics were more ready to undertake special work for the union (i.e. willingness) than ancillary staff. Both union instrumentality and passive participation (for example, voting in union elections) were strong predictors of all four factors of union commitment. Finally, active participation (for example, raising grievances) was observed to increase willingness to work for and belief in unionism. The results provide support for the generalisability of the factor structure of union commitment to New Zealand, where the implications for future research are discussed.

There is an extensive history to the study of trade unions. Scholars over the years have been fascinated with the purpose of unions, the roles unions perform, and why people form and join unions. Within the broader field of union studies are a large number examining employee attitudes towards trade unions. The historical cornerstone of such work stems from analysing the factors that lead employees to join unions (Deery and De Cieri, 1991). The current New Zealand industrial relations climate highlights the importance of understanding the types of relationships that may develop among members and their unions in an environment of unsponsored and voluntary unionism. Now more than ever it is important that unions identify and act on the motivators of union members' attachment and participation.

The ability to engender employees' commitment to the union is considered as a necessary precursor to union activism. Kuruvilla and Iverson (1993: 449) further assert that the "study of union commitment is of more than theoretical significance. An understanding of its

Roderick Iverson is a senior lecturer from the Department of Management and Industrial Relations, University of Melbourne. Matt Ballard is an Assistant Lecturer from the Department of Management, University of Otago. This paper was completed whilst the first author was on Special Studies Program leave. 
properties and determinants is important in attempting to arrest the slide of union membership

" However, there is still great debate in the literature regarding the dimensionality of union commitment. The present study adds to this growing body of literature by providing a rigorous examination of union commitment for the first time in a New Zealand setting. Our aim is to examine the stability of union commitment dimensions in the cultural context of New Zealand by employing the sophisticated technique of confirmatory factor analysis (LISREL VIII) (Jöreskog and Sörbom, 1993).

Union commitment represents the bonding of a member to his or her union. It is reflected by loyalty and positive behavioural union intentions (Gordon, Philpot, Burt, Thompson, and Spillers, 1980). Accordingly, union commitment is regarded as an essential membership attitude for unions wishing to both retain membership and create membership mobilisation when required.

Since the ability of union leaders to attain their goals is generally based on the members' loyalty, belief in the objectives of organised labor, and willingness to perform service voluntarily, commitment is part of the very fabric of unions (Gordon et al., 1980: 480).

Research on union commitment has been built upon the foundations of its more mature conceptual counterpart, organisational commitment. Organisational commitment possesses both attitudinal and behavioural components (for example, Allen and Meyer, 1990; Iverson, 1996). As an attitudinal or affective response to organisational relationships, commitment comprises those attitudes which reflect the extent to which an individual accepts or identifies with the goals, values and rewards of the organisation (Mowday et al., 1982). Behavioural organisational commitment (i.e. continuance or normative), in contrast, focuses on the process by which employees link themselves to an organisation, and the actions (for example, sidebets or moral obligations) by which they remain in the organisation (Cohen and Kirchmeyer, 1995).

Research has shown that although the same theoretical concepts of commitment apply across company and union organisations, organisational commitment models are poor predictors of members' commitment to a union (for example, Deery, Iverson and Erwin, 1994). In an attempt to address these misspecification problems, much attention has focused on utilising the union commitment model formulated in 1980 by Gordon and his colleagues. Deriving from the conceptual approaches of organisational commitment researchers, Gordon et al. (1980), defined union commitment as a desire to remain a member of the union, a willingness to put forth effort on behalf of the union, and a belief in and acceptance of the goals of the union. Hence, similar to organisational commitment, union commitment also possesses attitudinal and behavioural dimensions.

The two attitudinal or affective factors (union loyalty and belief in the union) relate to socialisation experiences, while the two behavioural factors (responsibility to the union and willingness to work for the union) are generally associated with union participation (Iverson and Buttigieg, 1995). The first factor of union loyalty has been defined as a sense of pride and instrumentality in the union (for example, degree to which members' values are similar to the union). Belief in unionism, the second factor, represents the individual's conviction in the concept of unionism (for example, degree of loyalty to the union in comparison to 
work) and like union loyalty represents more of a passive form of commitment. The third factor, responsibility to the union, is defined as a willingness to fulfil the day to day obligations of the union (for example, support another member with their grievances) and as such is considered as a custodial orientation toward one's role as a union member. Finally, willingness to work for the union has been defined as a readiness to undertake special work for the union (for example, run for elected office) which is "above and beyond the call of duty". It should be noted that the willingness factor is distinct from actual behavioural participation. Kelloway and Barling (1993) and Patterson and Johnson (1994) suggest that, conceptually, willingness to work for the union is most appropriately viewed as a behavioural intention to become involved in union activities. These authors, and others, have found that willingness to work for the union does directly affect participation (Iverson and Buttigieg, 1995). Thus, like responsibility to the union, willingness to work for the union represents a more active form of commitment.

In the following section we outline the continuing debate surrounding the factor structure of union commitment.

\section{Review of the dimensionality of union commitment}

As previously discussed, Gordon and his colleagues in 1980 provided the first systematic attempt to isolate the dimensionality of union commitment. Based on responses of a sample of United States white-collar union members to 48 different survey items, their exploratory factor analysis produced four dimensions of union commitment, which the authors labelled union loyalty, responsibility to the union, willingness to work for the union and belief in unionism. Although these four factors appeared to display construct validity and reliability, Gordon et al. (1980) requested replication of the questionnaire be undertaken in other research settings.

Following Gordon et al.'s (1980), recommendation, a steady stream of research has developed which replicates, validates and revises the union commitment scale. The rigour of Gordon et. al's scale has been well established. However, there has been much debate, scaling various national settings, about the most appropriate factor structure for making the scale operable.

In chronological order, the first two replications were undertaken in the United States. Ladd, Gordon, Beauvais and Morgan in 1982 compared union members in professional and nonprofessional occupations. The study confirmed that the four factors developed by Gordon et al. were consistent and generalisable across these populations. This result was also affirmed by Gordon, Beauvais, and Ladd (1984) studying engineers.

Fullagar (1986) tested the union commitment scale (using a shortened version with 28 items) on a sample of South African blue-collar workers in an attempt to establish external validity for the scale. Fullagar's findings concurred with the validity of the scale, but suggested a possible fifth factor of loyalty to the employing organisation and work. However, this factor appears to have developed through the racial distinction in the study's environment and has not received current support in the literature. Also in 1986, Friedman and Harvey performed 
research with the stated objective of lowering the dimensionality of the union commitment scale to two dimensions. Specifically, Friedman and Harvey claimed that the Gordon et al. study was unclear regarding the procedures that were used to make the number-of-factors decision. Re-analysing the Gordon et al. (1980) data using a different factor rotation technique (orthoblique rotation), Friedman and Harvey suggested two dimensions may better represent union commitment. The first factor in the model deals with the opinions, affect, and attitudes about the union held by union members. They labelled this factor union attitudes and opinions. A second factor they offered would measure the behavioural intentions of members regarding performance of prounion acts. This factor was labelled prounion behavioural intentions. Friedman and Harvey recommended that a shortened version of the Gordon et al. questionnaire (i.e. 19-items) could be used practically by researchers.

Klandermans (1989), in a study of blue collar workers in the Netherlands, identified six factors in an analysis of the Gordon et. al scale. However, in the final analysis Klandermans concluded that only two factors - loyalty and willingness - achieved strong internal consistency and construct validity. Thacker, Fields and Tetrick (1989) have also explored the union commitment scale. Specifically, these authors set out to test the appropriateness of the Gordon et al. and Friedman and Harvey factor structures on data collected from a sample of United States blue-collar employees. Thacker et al. made a number of observations but essentially settled on the opinion that the best fitting structure was the four factor approach of Gordon et al. However, the authors also suggested that either the four or two factor solution may be justified depending upon the research focus. Thacker, Fields and Tetrick further provided evidence for the reliability of the union commitment scale over time. Their longitudinal design used a span of eight months and measured union commitment through an abbreviated 28 -item scale. Through examination of test-retest results these authors concluded that the four dimensions to the union commitment model are stable and reliable across time.

Kuruvilla and Iverson (1993) in a Australian study of blue-collar employees also found support for the four-factor model of union commitment. Using confirmatory factor analysis, the results indicated that the best fitting model was the original Gordon et al. factor structure, where the factors of union loyalty, responsibility to the union, willingness to work for the union and belief in unionism displayed construct validity with a set of antecedent variables. Nonetheless, Kuruvilla and Sverke (1993) also found support for an alternate factor structure based on the model as reported by Friedman and Harvey (1989). Studying a sample of professional employees in Sweden, they observed the two-factors of union attitudes and opinions and prounion behavioural intentions to best represent union commitment.

More recently, Iverson and Kuruvilla (1995a) affirmed the Gordon et al. (1980) model. In an examination of elementary and high school teachers in the United States, they reported the four-factor structure to underpin union commitment. This was achieved by both confirmatory and exploratory factor analyses. Union loyalty was able to explain 40 percent of total variance, with responsibility to the union, willingness to work for the union and belief in unionism accounting for 13 percent, eight percent, and seven percent, respectively.

Although Kelloway, Catano, and Southwell (1992) have argued that the negatively worded items of the dimension belief in unionism may confound its interpretation as a factor and 
Iverson and Buttigieg (1995) have reported multi-collinearity problems between union loyalty and belief in unionism, we include all four-factors in our analysis of union commitment.

In summary, there are basically three possible explanations for the differences in factor structures across studies. First, union commitment may actually differ across cultures. Second, the differences in the dimensionality may be an artefact of the number and wording of items used in the survey instrument (for example, ranging from 11 to 48 items). Third, it would appear that the great variation in factor analysis techniques employed by studies (for example, exploratory versus confirmatory) contributes to the differential findings. In this paper we address these issues by employing methodology that identifies the most appropriate factor structure (Jöreskog and Sörbom, 1993) in New Zealand, followed by an examination of the construct validity of the various factors.

\section{Methods}

\section{Sample}

The site for this research was a university branch of the Association of University Staff (AUS) in New Zealand. The sample of 489 was equally divided between academic and ancillary (i.e. technical, library, general, and services) staff, with 59 percent being male. The average age and tenure of membership were 42.46 (S.D.=9.29) and 4.46 (S.D.=1.89), respectively.

\section{Data collection}

Using the records of the university branch of the AUS, all 913 members were surveyed. Respondents were informed that participation was voluntary and all information collected was confidential. Questionnaires were mailed to staff, with a total of 507 being returned by the close-out date. Following the visual scanning of the questionnaires, 18 were discarded as unusable. This represented a corrected response rate of 53 percent. Chi-square analysis was undertaken to evaluate the representativeness of the original population $(n=913)$ with that of the final sample $(\mathrm{N}=489)$. The results found no difference in the demographic characteristic of job category between academic and ancillary staff $\left(\chi^{2}(1)=0.47, p>.05\right)$. Although the AUS records did not permit other comparisons, the data would appear to be representative based on job category.

\section{Measurement}

A five-point Likert scale was used to measure the perceived response of each employee to items in the questionnaire (unless otherwise stated). The scale ranged from (5) strongly agree to (1) strongly disagree. The variables where possible were constructed from established scales and are specified in the sub-sections below. Cronbach's alpha (1951) was calculated for all multiple measures. The descriptive statistics and correlations (LISREL) among measures are contained in Table 2. 


\section{$\underline{\text { Union Commitment }}$}

Union commitment was measured by 22 items adopted from the 48 items identified by Gordon et al. (1980). As there is some concern regarding the functional equivalence of the items in other cultural contexts, we conducted a pilot study of eleven members of AUS. This enabled us to ground the survey within the New Zealand context and to eliminate any ambiguity or confusion in items. Also, as there were space and time restrictions, we were able to refine the questionnaire to meet these constraints.

As previously discussed, the empirical evidence for a four-factor structure of union commitment is not, however, universal. As reported in the last section, current research has reported the dimensionality of union commitment to vary considerably. We therefore undertook tests of the different factor structures of union commitment. The 22 items selected were first broken into the original four sub-scales as reported by Gordon and his colleagues: union loyalty (nine items), responsibility to the union (seven items), willingness to work for the union (four items), and belief in unionism (two items).

We also examined a three factor model by combining the loyalty and belief items into one scale, while keeping the willingness to work and responsibility items as two separate scales (for example, Fullagar, 1986; Klandermans, 1989). These were labelled, respectively, union attitudes and opinions (11 items), responsibility to the union (seven items), and willingness to work for the union (four items). In addition, there is strong evidence in the literature (for example, Kuruvilla and Sverke, 1993) indicating that union commitment may be better represented by two factors. We therefore grouped the 22 items into two sub-scales by combining the loyalty and belief items into one scale, and the willingness to work and responsibility items into the other. These were labelled, respectively, union attitudes and opinions (11 items) and behavioural intentions (11 items). A list of the items used is provided in the Table 3 .

\section{Explanatory Variables}

Several explanatory variables were included to assess the construct validity of union commitment. These comprised the demographic variables of age (years), gender (coded 1= male, $0=$ female), kinship responsibility (defined as the degree of an individual's obligation to immediate relatives in the community (Iverson, 1992), and membership tenure (years). Kinship responsibility was measured using a two-item composite index based on Blegen, Mueller, and Price (1988). The first-item relating to the number of people (including children or other relatives) depending on the respondent's income was coded as one if the respondent had one dependent, two if there were more than one dependent, and zero if there were no dependents. The second-item relating to whether the respondent was the main income earner was coded as one if the respondent was the main income earner and zero if they were not. The possible range of the index was between zero and three. The union variable of represented assessed whether the respondent had formally represented the AUS (coded 1=yes, $0=$ no). Both of the variables of job category (coded $1=$ academic, $0=$ technical, library, general, or services staff) and current rank of job category (ranging from $1=$ highest rank to 
$5=$ lowest rank) measured the respondent's position in the university. Union instrumentality, defined as the degree to which the union achieves valued goals of employees, (Deery, Erwin, and Iverson, 1996) was operationalised by eight items (for example, the benefits AUS provides exceed the cost of being a member). Passive participation focused on lower or informal forms of participation as assessed by six items (for example, since I have been a member I have always voted in AUS represenatitive elections), while active participation focused on higher or formal forms of participation as measured by the frequency of involvement with the AUS in the last twelve months (for example, number of times raised an issue or a grievance with AUS).

\section{Analytical methods}

The aim of our analysis was to examine the factor structure of union commitment in New Zealand. The analysis involves two basic procedures. First, we test the applicability of alternate factor structures using the confirmatory factor analysis techniques of LISREL VIII (Jöreskog and Sörbom, 1993). This technique allows us to examine the extent to which different factor structures better "fit" the data. In our analysis we specify five different models. The first model, the null model (i.e. a model that hypothesises that each item in the questionnaire represents a single factor by itself) establishes a baseline with which other models are compared in terms of the "fit" to the data. The second model ( 1 factor model) hypothesises that only one general factor underlies the commitment construct (i.e. the concept is unidimensional). The third model, 2 factor model, hypothesises that two factors best represent union commitment (for example, Friedman and Harvey, 1986; Klandermans, 1989; Kuruvilla and Sverke, 1993), while the 3 factor model, hypothesises that the three-factor solution will provide the best fit of the data. The final model derives from Gordon et al. (1980), which hypothesises a four-factor solution as best representing union commitment. Given that the factors of commitment are part of the general commitment construct, in the parameter specifications we allowed the different factors to be correlated (see Kuruvilla and Iverson, 1993 for a complete description of the measurement component of LISREL).

Evaluation of the various measurement models are made using conventional goodness-of-fit criteria (see Bentler, 1990 and Bentler and Bonnet, 1980 for a description of the virtues of various goodness of fit tests). We report and describe all the various indices below. The goodness-of-fit index (GFI) is an index of the amount of variance and covariance accounted for by the model; the adjusted goodness-of-fit (AGFI) is an index of the amount of variance and covariance explained, adjusted for the degrees of freedom in the model; the normed comparative fit index (CFI) is the preferred index for small samples, which is a population measure of comparative model misspecification (Bentler, 1990); the normed fit index (NFI) or rho compares the fit of the model to the null model when all items are constrained to be independent of each other (Bentler and Bonett, 1980); the parsimonious fit index (PFI) or delta corrects the NFI by adjusting for the degrees of freedom for the model (James, Mulaik and Brett, 1982); and the root mean square residual (RMSR) is the result of the subtraction of the hypothesised covariance matrix from the sample covariance matrix (Jöreskog and Sörbom, 1993). For the GFI, AGFI, CFI, NFI, and the PFI, the values range from zero to one, with higher values representing better fit. For the RMSR, lower values indicate better fit. 
We rely on the PFI for evaluating the various models. The advantage of the PFI is that it indicates the practical significance in difference of fit for competing models (for example, Harvey, Billings, and Nilan 1985; Iverson and Kuruvilla, 1995b). Finally, to establish whether the fit of one model is significantly different from the fit of another model we employ a nested approach, where chi-square difference tests are used to indicate improved fit (Bentler and Bonett, 1980).

The second step in our analysis involves demonstrating the construct validity of the bestfitting model. Although, we expect the factors of commitment to be related, they also should be significantly different from each other. To examine the construct validity of the factors, we regressed them on a set of explanatory variables. The explanatory variables (i.e. age, gender, kinship responsibility, membership tenure, represented, job category, rank, union instrumentality, passive and active participation) have been linked to union commitment (for example, Barling et al., 1992; Gallagher and Clark, 1989). If the factors of commitment are distinct, then we would expect differential relationships between the factors and the explanatory variables.

\section{Results}

Table 1 provides the confirmatory factor analysis results for models of differing dimensionality. The four-factor (i.e. union loyalty, responsibility to the union, willingness to work for the union, and belief in unionism) solution provides the statistically best fitting model. This was indicated by the change in chi-square and the associated improvement in the goodness-of-fit for the PFI as we proceeded from the null model to the four-factor model. This was also affirmed by the increase in the PFI from .649 to .801 , which exceeded Widaman's (1985) "rule of thumb" of .01 criterion for the practical improvement of the models. Specifically, the one-factor model provided a significant improvement in fit over the null model $\left(\chi^{2}(22)=2780.70, p<.05\right)$. The two-factor model represented a better fit of the data than the one-factor model $\left(\chi^{2}(1)=288.42, p<.05\right)$, as did the three-factor model over the two-factor model $\left(\chi^{2}(2)=281.27, p<.05\right)$. Finally, the four-factor model was a significant improvement in regards to the three-factor model $\left(\chi^{2}(3)=11.91, p<.05\right)$. Although the PFI of the four-factor model was only slightly higher than that for the three-factor model, the chisquare difference results clearly indicate that the four-factor solution best fits the data. This is also affirmed in Table 3 which contains the LISREL estimates of the factor loadings for each of the four-factors. All loadings are significant, with the total coefficient of determination (.995) indicating that the fit of the measurement model is extremely good. In addition, examination of the LISREL modification indices suggests that the fit of the model would not be significantly improved by allowing items to load on other factors.

Examining Table 2 it is evident that all four factors were significantly related. The correlations ranged between .48 and $.85(\mathrm{p}<.05)$, with the attitudinal dimensions of union loyalty and belief in unionism as expected being the most highly associated. To evaluate the construct validity of the best fitting model, we undertook LISREL analysis of the different antecedents of the four-factors (see Table 4). 
As Table 4 indicates, the four-factors appear differentially related to the explanatory variables. This is also supported by the R-square for each commitment factor, which differs markedly. For example, the models explain about 90 percent of the variance in union loyalty, 46 percent of the variance in responsibility to the union, 44 percent of the variance in willingness to work for the union, and 62 percent of the variance in belief in unionism. This would suggest that the four factors are distinct.

A brief analysis of the results displays some interesting relationships between the explanatory variables and the union commitment factors. In terms of age, we found that older staff are more willing to fulfil the day to day obligations of the union (Barling et al., 1992; Gallagher and Clark, 1989). Although Gordon et al. (1980) reported that women tend to exhibit greater loyalty to the union, but are less inclined to be willing to work for the union, we found no support for the effects of gender (Kuruvilla and Iverson, 1993). This finding is also affirmed by Gallagher and Clark (1989) and Kuruvilla et al. (1993) who argue that the relationship between gender and union commitment is inconclusive and lacks any theoretical rationale. Kinship responsibility, which because of the external family obligations was thought to decrease the behavioural components of responsibility and willingness to work for the union, was also found not to have an impact on any of the factors (Iverson and Kuruvilla, 1995a). Surprisingly, membership tenure displayed a similar relationship (Barling et al., 1992).

Having represented or held a union position in the past significantly increases staff's responsibility and willingness to work for the union. This may be due to staff having greater access to information about the union, accompanied by positive experiences with the union (Kuruvilla and Iverson, 1993). Interestingly, academics rather than ancillary staff displayed greater readiness to undertake special work for the union (Kuruvilla and Iverson, 1993). This may highlight the greater flexibility in work arrangements of academics. Being ranked high or low in job category or classification was found not to influence union commitment.

Two of the strongest predictors of union commitment were union instrumentality and passive participation (Deery et al., 1996; Iverson and Kuruvilla, 1995a; Kuruvilla et al., 1993). These variables had significant positive effects on all four factors. A possible explanation for the very high relationship between union instrumentality and union loyalty stems from union loyalty partially capturing instrumentality aspects (Gordon et al., 1980). As union instrumentality measures the degree to which the union achieves valued goals of employees, it is logical to expect members to increase their custodial orientation toward the union, while displaying a high degree of altruism for union activities. Although there is some debate over the causal ordering of participation-commitment (Iverson and Kuruvilla, 1995a), our results clearly demonstrate that staff displaying lower forms of participation (for example, voting in elections) also display both attitudinal and behavioural union commitment. Finally, as anticipated active participation (for example, raising grievances) was associated with increased behavioural intentions of willingness to work for the union (Kelloway et al., 1992) and belief in unionism. Higher forms of participation were contemplated to be linked with more active forms of commitment. 
In summary, the findings support Gordon et al.'s (1980) four-factor model of union loyalty, responsibility to the union, willingness to work for the union, and belief in unionism. Moreover, the factors displayed discriminant validity with the explanatory variables as evidenced by the differential relationships and explained variances.

Table 1: Goodness-of-fit of alternate factor model specifications in New Zealand

Model $\quad \chi^{2} \quad d f \quad p<. \quad$ GFI AGFI RMSR CFI NFI PFI

\begin{tabular}{llllllllllll}
\hline Null & 4075.94 & 231 & 000 & .327 & .263 & .299 & - & - & - \\
1 Factor & 1295.24 & 209 & 000 & .771 & .723 & .079 & .717 & .682 & .649 \\
2 Factor & 1006.82 & 208 & 000 & .818 & .779 & .070 & .792 & .753 & .726 \\
3 Factor & 725.55 & 206 & 000 & .868 & .838 & .067 & .865 & .822 & .800 \\
4 Factor & 713.64 & 203 & 000 & .872 & .841 & .067 & .867 & .825 & .801 \\
& & & & & & & & & \\
\hline
\end{tabular}


Table 2: Means, standard deviations, correlations (LISREL), and reliabilities ${ }^{\mathrm{ab}}$

हี่

\section{Number}

of

Determinants

Items Means s.d.

$\begin{array}{llllll}9 & 3.13 & 0.67 & .83 & & \\ 7 & 3.84 & 0.61 & .72 & .77 & \\ 4 & 2.55 & 0.96 & .54 & .60 & .84 \\ 2 & 2.92 & 0.92 & .85 & .66 & .48\end{array}$

.60

Union Commitment
1. Loyalty
2. Responsibility
3. Willingness
4. Belief

$\begin{array}{ll}2 & 2.92\end{array}$

Explanatory Variables
5. Age
6. Gender
7. Kinship
8. Member tenure
9. Represented
10. Job category
11. Rank
12. Union instrumentality
13. Passive participation
14. Active participation

$\begin{array}{lll}1 & 42.46 & 9.29 \\ 1 & 0.59 & 0.49\end{array}$

$\begin{array}{lll}1 & 42.46 & 9.29 \\ 1 & 0.59 & 0.49 \\ 1 & 1.99 & 0.62\end{array}$

$\begin{array}{lll}1 & 0.59 & 0.49 \\ 1 & 1.99 & 0.62\end{array}$

$\begin{array}{lll}1.99 & 0.62 \\ 1.89\end{array}$

$\begin{array}{lll}1 & 0.17 & 0.38\end{array}$

$\begin{array}{lll}1 & 0.50 & 0.50 \\ 1 & 3.15 & 1.16\end{array}$

$\begin{array}{lll}1 & 0.50 & 0.50 \\ 1 & 3.15 & 1.16\end{array}$

$\begin{array}{lll}1 & 3.15 & 1.16 \\ 8 & 3.22 & 0.68\end{array}$

$\begin{array}{lll}8 & 3.22 & 0.68 \\ 6 & 3.18 & 0.79 \\ 3 & 2.41 & 2.54\end{array}$

$\begin{array}{lll}3 & 2.41 & 2.54\end{array}$

\begin{tabular}{rr}
-.03 & .08 \\
-.06 & -.03 \\
-.02 & -.02 \\
-.05 & -.01 \\
.20 & .27 \\
-.01 & -.04 \\
.13 & .07 \\
.93 & .58 \\
.50 & .52 \\
.24 & .28 \\
\hline
\end{tabular}

$.08-.03$

$\begin{array}{ccc}.03 & -.02 & -- \\ .02 & -.04 & .14 \\ .02 & -.01 & .14\end{array}$

${ }^{a} \mathrm{~N}=484$. Reliabilities are reported along the diagonal.

${ }^{\mathrm{h}}$ Correlations above .08 are significant at $\mathrm{p}<.05$, one-tailed test. 
Table 3: Union commitment items and factor loadings for the four factor solution

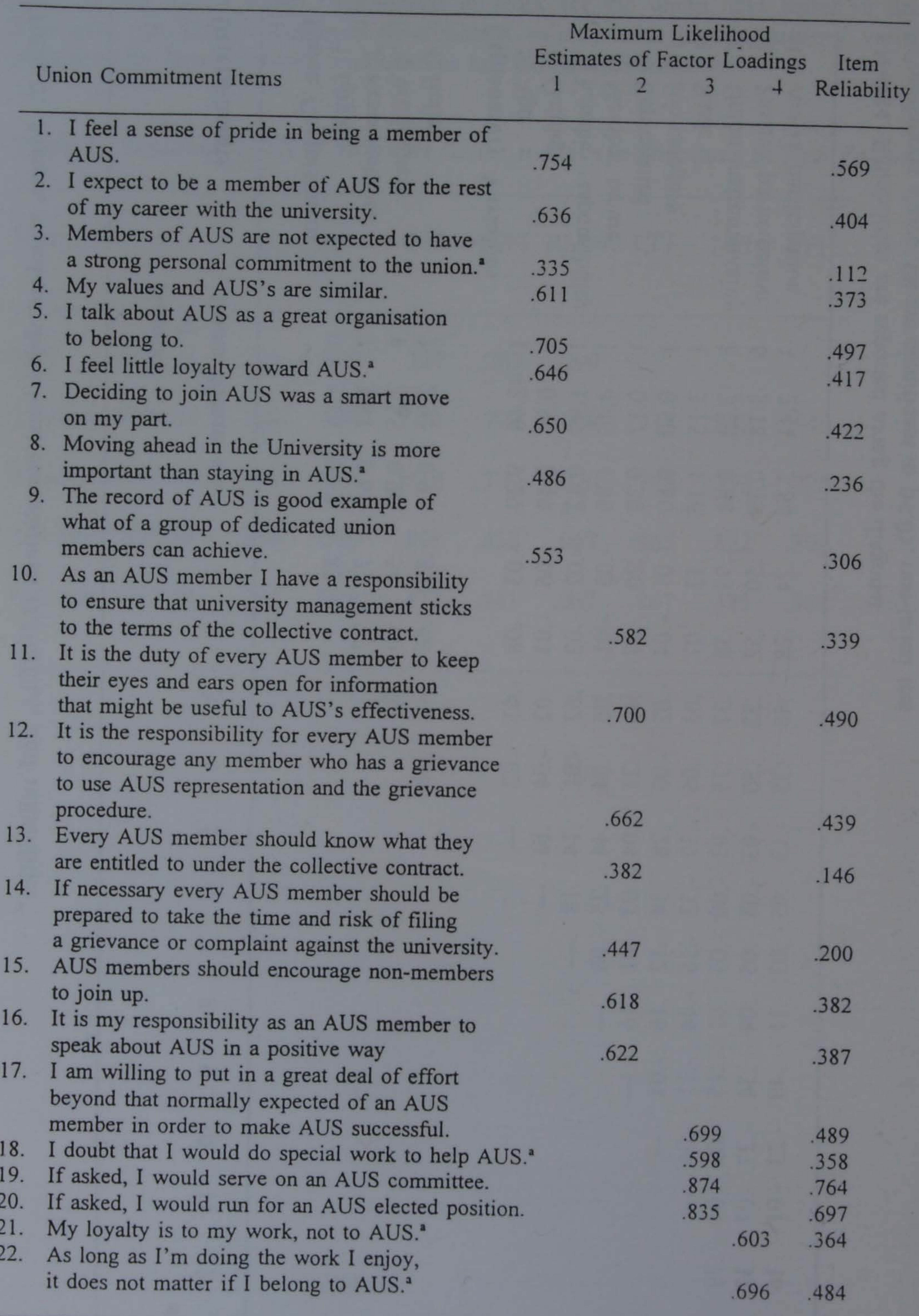

Notes: Total coefficient of determination is .995 .

${ }^{2}$ Reverse coded. 
Table 4: LISREL estimates for determinants of union loyalty, responsibility to the union, willingness to work for the union, and belief in unionism

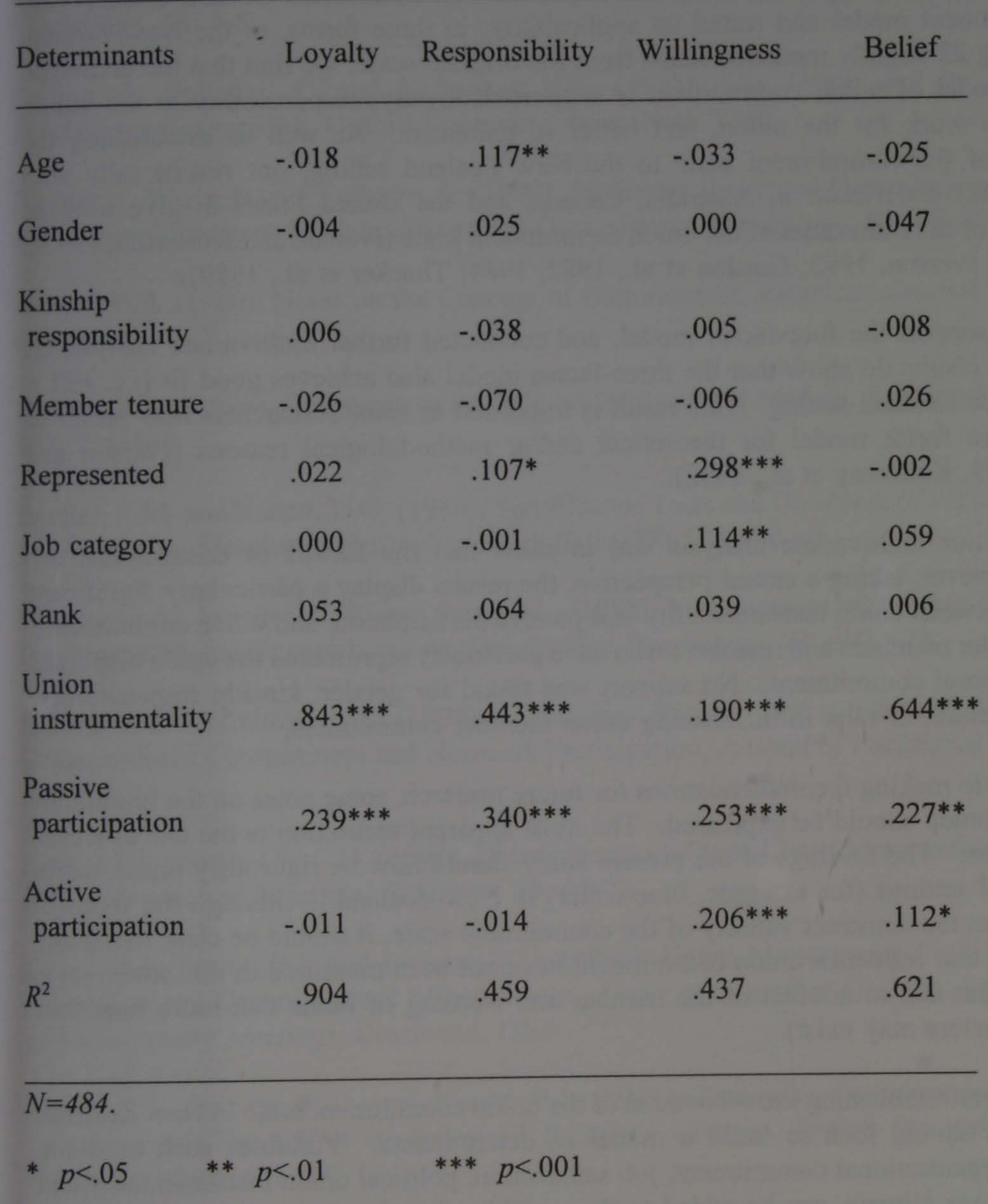




\section{Conclusions}

To date little empirical research has been done in New Zealand examining the commitment of union members. The present study has taken the well established Gordon et al. (1980) union commitment model and tested its applicability, in three forms, to the New Zealand setting. Using 22 slightly modified items from the original scale, we find that the archetype four-factor model of union commitment is supported: loyalty, responsibility to the union, willingness to work for the union, and belief in unionism. As well as establishing the applicability of the commitment scale to the New Zealand setting, our results tally with previous studies undertaken in Australia, Canada, and the United States to give a broad endorsement for the robustness of the union commitment scale (Iverson and Kuruvilla, 1995a, Kuruvilla and Iverson, 1993; Gordon et al., 1982, 1984; Thacker et al., 1989).

Although we support the four-factor model, and conducted further multivariate analysis on this basis, the results do show that the three-factor model also achieves good fit (i.e. PFI = .80 ) in the New Zealand setting. This result is important as some researchers may prefer to adopt the three factor model for theoretical and/or methodological reasons (Iverson and Buttigieg, 1995; Kelloway et al., 1992).

The focus of our multivariate analysis was to show that the factors of commitment are different. However, taking a causal perspective, the results display a particularly significant relationship between union instrumentality and passive participation, and union commitment. In addition, older members and members who have previously represented the union displayed higher behavioural commitment. No support was found for gender, kinship responsibility, membership tenure, or rank in influencing union member commitment.

As a precursor to making recommendations for future research, some notes on the limitations of the present study should be expressed. The most apparent restriction is the use of a case study population. The findings of the present study should now be rigorously replicated in other unionised settings (for example, blue-collar) in New Zealand. Although the focus of our analysis was the construct validity of the commitment scale, it should be clear that many other variables that influence union commitment have not been measured in this study. It is also possible that due to artefact of the number and wording of items that more than four commitment factors may exist).

As well as further establishing the robustness of the union commitment scale in New Zealand, future research should look to build a model of determinants. Variables such as union socialisation, organisational commitment, job satisfaction, political union instrumentality and industrial relations climate, can be added to the variables found to be useful in this study age, represented, instrumentality and participation - in building a causal model. While longitudinal research designs have recently begun to be employed in this area (Fullagar, Clark, Gallagher, and Gordon, 1994), further work is required. The onus is therefore on researchers in New Zealand and overseas to take up this challenge in attempting to establish the temporal and causal dimensionality of union commitment. 


\section{References}

Allen, N.J. and Meyer, J.P. (1990), The Measurement and Antecedents of Affective, Continuance, and Normative Commitments to the Organization, Journal of Occupational Psychology, 63: 1-8.

Barling, J., Fullagar, C. and Kelloway, E.K. (1992), The Union and its Members: A Psychological Approach, Oxford University Press, New York.

Barling, J., Wade, B. and Fullugar, C. (1990), Predicting Employee Commitment to Company and Union: Divergent Models, Journal of Occupational Psychology, 63: 49-61.

Becker, H.S. (1960), Notes on the Concept of Commitment, American Journal of Sociology, 66: $32-42$.

Bentler, P.M. (1990), Comparative Fit Indexes in Structural Models, Psychological Bulletin, 107: 238-246.

Bentler, P.M. and Bonett, D.G. (1980), Significance Tests and Goodness of Fit in the Analysis of Covariance Structures, Psychological Bulletin, 88: 588-606.

Blegen, M.A., Mueller, C.W. and Price, J.L. (1988), Measurement of Kinship Responsibility for Organizational Research, Journal of Applied Psychology, 73: 402-409.

Cohen, A. and Kirchmeyer, C. (1995), A Multidimensional Approach to the Relation between Organizational Commitment and Nonwork Participation, Journal of Vocational Behavior, 46: 189-202.

Deery, S.J. and De Cieri, H. (1991), Determinants of Trade Union Membership in Australia, British Journal of Industrial Relations, 29: 59-73.

Deery, S.J., Erwin, P.J. and Iverson, R.D. (1996), Union Management Co-Operation, Dual Allegiance and Organizational Effectiveness, Paper presented at the 56th Annual Academy of Management Meetings, Cincinnati, Ohio.

Deery, S.J., Iverson, R.D. and Erwin, P.J. (1994), Predicting Organizational and Union Commitment: The Effect of Industrial Relations Climate, British Journal of Industrial Relations, 32(4): 581-597.

Dunham, R.B., Grube, J.A. and Castaneda, M.B. (1994), Organizational Commitment: The Utility of an Integrative Definition, Journal of Applied Psychology, 79(3): 370-380.

Friedman, L. and Harvey, R.J. (1986), Factors of Union Commitment: The Case for a Lower Dimensionality, Journal of Applied Psychology, 71: 371-376. 
Fukami, C.V. and Larson, E.W. (1984), Commitment to Company and Union: Parallel Models, Journal of Applied Psychology, 69: 367-371.

Fullagar, C. (1986), A Factor Analytic Study on the Validity of a Union Commitment Scale, Journal of Applied Psychology, 71: 129-136.

Fullagar, C., Clark, P., Gallagher, D. and Gordon, M.E. (1994), A Model of the Antecedents of Early Union Commitment: the Role of Socialization and Steward Characteristics, Journal of Organizational Behavior, 15: 517-533.

Fullagar, C. and Barling, J. (1987), Towards a Model of Union Commitment. In Lipsky, D., and Lewin, D. (Eds), Advances in Industrial and Labor Relations, JAI Press, Connecticut.

Gallagher, D.G. and Clark, P.F. (1989), Research on Union Commitment: Implications for Labor, Labor Studies Journal, 14: 52-71.

Gordon, M.E., Beauvais, L.L. and Ladd, R. T. (1984), The Job Satisfaction and Union Commitment of Unionized Engineers, Industrial and Labor Relations Review, 37: 359-370.

Gordon, M.E., Philpot, J.W., Burt, R.E., Thompson, C.A. and Spiller, W.E. (1980), Commitment to the Union: Development of a Measure and an Examination of its Correlates, Journal of Applied Psychology, 65: 479-499.

Hackett, R.D., Bycio, P. and Hausdorf, P.A. (1994), Further Assessments of Meyer and Allen's (1991) Three-Component Model of Organizational Commitment, Journal of Applied Psychology, 79(1): 15-23.

Harvey, R.J., Billings, R.S. and Nilan, K.J. (1985), Confirmatory Factor Analysis of the Job Diagnostic Survey: Good News and Bad News, Journal of Applied Psychology, 70: 461-468.

Iverson, R.D. (1996), Employee Acceptance of Organizational Change: The Role of Organizational Commitment, International Journal of Human Resource Management, 7, 122149.

Iverson, R.D. (1992), Employee Intent to Stay: An Empirical Test of a Revision of the Price and Mueller model, (unpublished doctoral dissertation), The University of Iowa.

Iverson, R.D. and Buttigieg, D. (1995), Union Commitment: Implications for Union Participation and Exit-voice, Labour and Industry, 6(3): 95-111.

Iverson, R.D. and Kuruvilla, S. (1995a), Antecedents of Union Loyalty: The Influence of Individual Dispositions and Organizational Context, Journal of Organizational Behavior, 16: 557-582. 
Iverson, R.D. and Kuruvilla, S. (1995b), Does dual commitment underlie company and union commitment? Evidence from Australia, Sweden and the United States, Research and Practice in Human Resource Management, 3(1): 15-38.

Iverson, R.D. and Roy, P. (1994), A Causal Model of Behavioural Commitment: Evidence from a Study of Australian Blue-Collar Employees, Journal of Management, 20(1): 15-41.

James, L.R., Mulaik, S.A. and Brett, J.M. (1982), Causal Analysis, Sage, Beverly Hills.

Jaros, S.J., Jermier, J.M., Koehler, J.W. and Sincich, T. (1993), Effects of Continuance, Affective, and Moral Commitment on the Withdrawal Process: An Evaluation of Eight Structural Equation Models, Academy of Management Journal, 36(5): 951-995.

Jöreskog, K.G. and Sörbom, D. (1993), LISREL 8: User's Reference Guide, Scientific Software International, Chicago.

Kelloway, E.K., Catano, V.M. and Southwell, R.E. (1992), Construct Validity of Union Commitment: Development and Dimensionality of a Shorter Scale, Journal of Occupational and Organizational Psychology, 65: 197-211.

Kelloway, K.E. and Barling, J. (1993), Members' Participation in Local Union Activities: Measurement, Prediction and Replication, Journal of Applied Psychology, 78: 262-279.

Klandermans, B. (1989), Union Commitment: Replications and Tests in the Dutch Context, Journal of Applied Psychology, 74: 869-875.

Kuruvilla, S. and Iverson, R.D. (1993), A Confirmatory Factor Analysis of Union Commitment in Australia, Journal of Industrial Relations, 35(3): 436-452.

Kuruvilla, S. and Sverke, M. (1993), Two Dimensions of Union Commitment Based on a Theory of Reasoned Action, Research and Practice in Human Resource Management, 1: 1-16.

Ladd, R.T., Gordon, M.E., Beauvais, L.L. and Morgan, R.L. (1982), Union Commitment: Replication and Extension, Journal of Applied Psychology, 67: 640-644.

Marsh, G. and Richards, H. (1987), Multidimensionality of the Rotter scale, Multivariate Behavioral Research, 22: 39-71.

Mowday, R.T., Porter, L.W. and Steers, R.M. (1982), Employee-Organization Linkages: The Psychology of Commitment, Absenteeism and Turnover, Academic Press, New York.

Patterson, C.R. and Johnson, W.R. (1994), A Test of Union Participation For Public Sector Employees in the United States, Paper presented at The Psychology of Industrial Relations Under Changing Employment Relationships: An International Perspective at Wayne State University, Detroit, Michigan. 


\section{Iverson and Ballard}

Porter, L.M., Steers, R.M., Mowday, R.T. and Boulian, P.V. (1974), Organizational Commitment, Job Satisfaction, and Turnover Amongst Psychiatric Technicians, Journal of Applied Psychology, 59: 603-609.

Thacker, J.W., Fields, M.W. and Barclay, L.A. (1990), Union Commitment: An Examination of Antecedent and Outcome Factors, Journal of Occupational Psychology, 63: 33-48.

Thacker, J.W., Fields, M.W. and Tetrick, L.E. (1989), The Factor Structure of Union Commitment: An Application of Confirmatory Factor Analysis, Journal of Applied Psychology, 74: 228-232.

Widaman, K.F. (1985), Hierarchically Nested Covariance Structure Models For Multitraitmultimethod Data, Applied Psychological Measurement, 9: 1-26. 